\title{
COVID-19 and Oral Surgery: A narrative review of preoperative
} mouth rinses

\section{COVID-19 i oralna kirurgija: narativni pregled važnosti preoperativnog ispiranja usne šupljine}

\footnotetext{
${ }^{1}$ Department of Implantology and Oral Rehabilitation, IRCCS Istituto Ortopedico Galeazzi, Dental Clinic, Director Prof. L. Francetti, Milan, Italy. Odjel za implantologiju i oralnu rehabilitaciju IRCCS-ova Ortopedskoga instituta Galeazzi - Stomatološka klinika, Milano, Italija

2 Professor and Director of Graduate Periodontics, Department of Periodontics and Oral Medicine, School of Dentistry, University of Michigan, Ann Arbor, Michigan, USA

Odjel za parodontologiju i oralnu medicinu Stomatološkog fakulteta Sveučilišta Michigan, Ann Arbor, SAD

${ }^{3}$ Minimally Invasive Aesthetic and Digital Oral Rehabilitation Centre (CROMED), IRCCS Istituto Ortopedico Galeazzi, Dental Clinic (Director Prof. L. Francetti), Milan, Italy.

Odjel za biomedicinske, kirurške i stomatološke znanosti Sveučilišta u Milanu, Italija Minimalno invazivni centar za estetsku i digitalnu oralnu rehabilitaciju (CROMED) IRCCS-ova Ortopedskoga instituta Galeazzi - Stomatološka klinika, Milano, Italija

${ }^{4}$ Private practice, Milan, Italy.

Privatna ordinacija, Milano, Italija

${ }^{5}$ Department of Endodontics and Restorative Dentistry, School of Dental Medicine, University of Zagreb, 10000, Zagreb, Croatia.

Zavod za endodonciju i restaurativnu stomatologiju Stomatološkog fakulteta Sveučilišta u Zagrebu, Hrvatska.

${ }^{6}$ IRCCS Istituto Ortopedico Galeazzi, Dental Clinic, Milan, Italy. Associate Professor, Department of Biomedical, Surgical and Dental Sciences, University of Milan, Milan, Italy.

Odjel za biomedicinske, kirurške i stomatološke znanosti Sveučilišta u Milanu, Italija. IRCCS-ov Ortopedski institut Galeazzi - Stomatološka klinika, Milano, Italija
}

\begin{abstract}
Objective: To provide a narrative review of the preprocedural mouth rinse protocols suggested for oral surgery in order to contrast the presence of SARS-CoV-2 in aerosol. Sources and Methods: Electronic searches were performed in medical databases PubMed, Medline, CINAHN and Scopus to identify relevant studies published up until the third week of April 2020. This research was supplemented by exploration through a web-based search engine as well as a manual search for international and national guidelines. Studies and protocols which suggested preoperative mouth rinsing as a recommended measure during the COVID-19 outbreak were included. Given the small number of studies, a narrative literature review was conducted. In total, 15 references (11 articles and 4 guidelines) were considered relevant and were critically analysed. Conclusion: The findings show a high heterogeneity in the protocols suggested. Further research is required to better understand the viral features and epidemiologic characteristics of this new virus and to test the efficacy of commonly used antiseptics against SARS-CoV-2 in future clinical trials. However, the use of chlorhexidine, hydrogen peroxide, PVP-I and cetylpyridinium chloride in contrasting the spread of Covid-19 is described as advisable and substantial in different publications.
\end{abstract}

Received: June 22, 2020

Accepted: September 24, 2020

Address for correspondence Dr. Matteo Basso

Via R. Galeazzi 4, 20161 Milano, Italy matteo.basso@unimi.it-www. matteobasso.it

Key words

SARS Virus; Occupational Exposure; Mouthwashes; Clinical Protocols; Local Anti-Infective Agents

\section{Introduction}

Dentists present the greatest risk of exposure of medical practitioners to the infection of COVID-19, as they are brought in much closer contact with patients than is the case with practitioners in other fields of medicine (1). Oral surgery procedures, such as implant placement, immediate loading procedures, complex tooth extractions or guided bone regenerations, require the use of tools and devices which produce aerosol and spatters. Surgical areas contain many devices such as implant and surgical motors, anaesthesiologic pumps, surgical lamps, blood centrifuges, which are not normally present in standard dental rooms.

\section{Uvod}

Od svih su liječnika doktori dentalne medicine izloženi najvećem riziku od bolesti uzrokovane virusom COVID-19 jer su u bliskom kontaktu s usnom šupljinom pacijenta (1). Zahvati u oralnoj kirurgiji, poput postavljanja implantata, složenih vađenja zuba ili vođene regeneracije kosti, zahtijevaju uporabu uređaja koji proizvode aerosol kao što su implantacijski i kirurški motori, anesteziološka pumpa kirurška svjetiljka i centrifuga za krv.

Upravo zbog toga, tijekom stomatoloških postupaka, doktori dentalne medicine i oralni kirurzi izloženi su velikim količinama aerosola $s$ mnoštvom mikroorganizama (2). 
Therefore, dentists and oral surgeons are exposed to high quantities of spray produced by dental instruments placed inside the mouth, where many microorganisms can be found (2). Since SARS-CoV-2 has a very high affinity not only for the epithelial cells of the lungs but also for those of the salivary glands, a considerable amount of the virus is continuously excreted with saliva in infected subjects $(3,4)$. From there, it can pass into the aerosol created during the procedures and be inhaled by the operator. The same principle applies for all devices which produce spray, such as ultrasonic scalers, surgical implant motors and the air-water syringe found in dental units $(2,6-8)$.

Dental aerosols produced during surgical procedures can contain a large number of bacteria and viruses $(8,9)$. It has been established that microorganisms in dental aerosols can still cause infections after remaining in an environment for extended periods although there is no definite evidence of transmission of infectious pathogens through dental aerosols (6,8,10-13).

Van Doremalen (14) and Chin (15) tested the presence of the SARS-CoV-2 on different materials. They reported that on several materials such as plastic, stainless steel and surgical masks the virus can be detected for up to 4 days (Figure 1).

Moreover, the high risk of transmission of the virus, the exponential increase in positive cases and the existence of asymptomatic or paucisymptomatic carriers with a high viral load obliges dental practice staff to consider all patients undergoing a surgical procedure as potentially infected, even if the relative transmissibility of asymptomatic COVID-19 infections it is not yet fully clear (16-18). The aim of the present study was to identify in the available literature, the role, possible uses, efficacy and side effects of different active ingredients contained in many common mouthwashes against the new SARS-CoV-2 with special consideration of surgical dental procedures.

\section{Material and methods}

An online review of scientific articles was performed using medical databases such as PubMed, MedLine, CINAHN and Scopus. Due to the overall small number of relevant publications, single publications as well as digital articles on websites were included in the initial search. With the keywords "COVID" and "dentistry" or "dental" or "oral surgery", 48 references were found by the date of $31^{\text {st }}$ of August 2020. Possible duplicates were excluded based on article titles. Furthermore, all abstracts underwent an initial screening to eliminate articles which were not related to our aim of establishing the possible uses of different active ingredients in the common mouth washing agents. Several international guidelines published in different countries ( 5 in total) have also been found (Figure 1).

After the initial screening and the exclusion of duplicates and studies not relevant to the topic, the full texts of candidate sources in the field of dentistry regarding the pathology of COVID-19 until $1^{\text {st }}$ of September 2020 were analysed. Although the content of the articles was wide-ranging, a large
Budući da virus SARS-CoV-2 ima visoki afinitet, ne samo za epitelne stanice pluća, nego i za žlijezde slinovnice, zaražene osobe kontinuirano slinom izlučuju znatnu količinu virusa $(3,4)$. Na taj način virus može prijeći u aerosol $(5)$ stvoren tijekom postupaka te ga doktor dentalne medicine može udahnuti. To se odnosi i na sve uredaje koji proizvode sprej, poput ultrazvučnih, kirurških i implantacijskih motora te štrcaljki zrak-voda koje su dio zubnih jedinica $(2,6-8)$.

Zubni aerosoli proizvedeni tijekom kirurških zahvata mogu sadržavati mnogobrojne bakterije i viruse $(8,9)$. Utvrdeno je da mikroorganizmi iz aerosola mogu prouzročiti infekcije čak i nakon što su dulje u okolišu $(8,10-13)$, premda nema sigurnih dokaza o prijenosu zaraznih patogena zubnim aerosolima (6). Van Doremalen (14) i Chin (15) testirali su prisutnost virusa SARS-CoV-2 na različitim materijalima te su dokazali da se može zadržati do četiri dana na plastici, nehrđajućem čeliku i kirurškoj maski (Slika 1.). Štoviše, visok rizik od prijenosa virusa, eksponencijalni porast pozitivnih slučajeva i asimptomatski pacijenti s velikim virusnim opterećenjem $(16,17)$ obvezuju osoblje ordinacije dentalne medicine da sve pacijente koji se podvrgavaju kirurškom zahvatu smatraju potencijalno zaraženima, iako relativna prenosivost asimptomatskih infekcija virusom COVID-19 još nije potpuno jasna (18).

Cilj je ovog istraživanja utvrditi, prema dostupnoj literaturi, utjecaj, mogućnost korištenja, djelotvornost i nuspojave različitih aktivnih sastojaka sadržanih u mnogim uobičajenim vodicama za ispiranje usta na novi virus SARS-CoV-2, s posebnim osvrtom na kirurške stomatološke zahvate.

\section{Materijali i metode}

Pretražene su znanstvene baze podataka PubMed, MedLine, CINAHN i Scopus. Zbog sveukupno malog broja mjerodavnih časopisa, pojedinačne publikacije i digitalni članci na mrežnim stranicama uključeni su u početno istraživanje. Uz ključne riječi COVID i stomatologija ili dentalna medicina ili oralna kirurgija, pronađeno je 48 radova do 31. kolovoza 2020. Mogući duplikati izuzeti su na temelju naslova članaka. Nadalje, sažetci radova bili su podvrgnuti dodatnom pregledu kako bi se uklonili radovi u kojima se opisuju proizvodi, a nisu povezani s utvrđivanjem moguće uporabe različitih aktivnih sastojaka u uobičajenim sredstvima za ispiranje usne šupljine. Pronađeno je i nekoliko međunarodnih smjernica objavljenih u različitim zemljama (ukupno 5).

Nakon početnog probira i izuzimanja duplikata i studija koje nisu relevantne za temu, analizirani su cjeloviti tekstovi iz područja dentalne medicine u vezi s patologijom virusa COVID-19 do 1. rujna 2020. Za obrađenu temu ispiranja usne šupljine, u rujnu 2020. pronađeno je samo nekoliko tekstova (ukupno 23 referencije, 19 članaka i 4 smjernice) s 


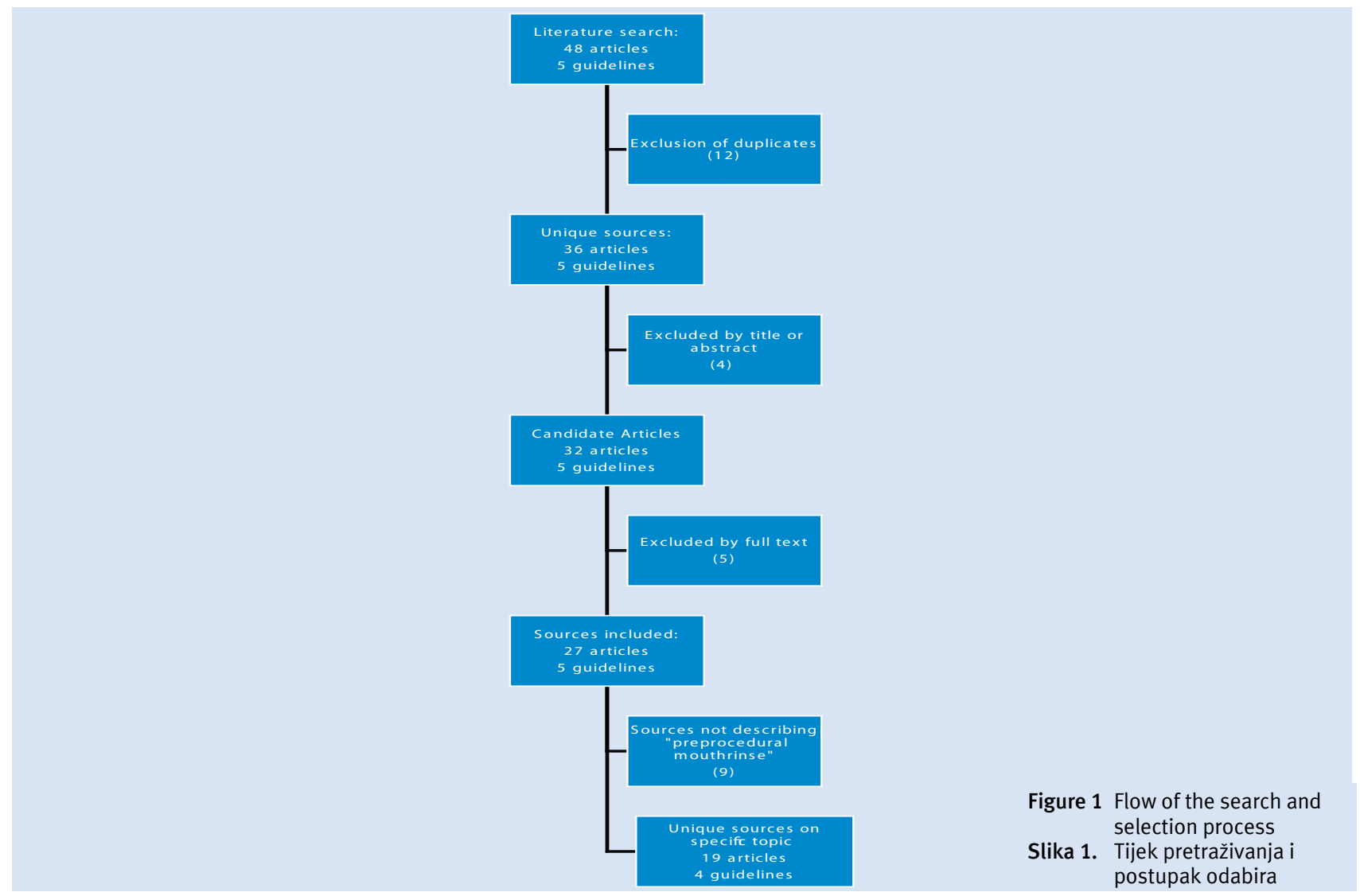

number of them were able to provide recommendations for ensuring the safety and protection of the operator during oral surgery. On the specific topic of mouth rinses, in September 2020, just a few publications (23 references in total, 19 articles and 4 guidelines) have been found with the keywords "COVID" and "Mouth rinse" or "Mouthwash". However, only one article, with a limited analysis, was specifically related to the field of oral surgery.

\section{Results}

Given the relative ignorance of current medicine on this virus, which emerged only at the end of 2019, it is not surprising that limited data are yet available to show whether an active ingredient present in a mouthwash can be effective when used as a pre-procedural rinse or as a home rinse by a patient with COVID-19. In late August 2020, only a limited number of publications related to SARS-CoV-2 and dentistry were available, and only few of them proposed different kinds of active substances as pre-procedural mouth rinses: hydrogen peroxide $1 \%$, povidone-iodine $1 \%$ (PVPI), cetylpyridinium chloride (CPC) $0.1 \%$, essential oils and chlorhexidine. Essential conclusions of cited publications are reported in Table 1 . It is immediately evident that there is a high degree of heterogeneity between these protocols proposed; hence a critical review analysis is proposed to lead the clinicians' choices.

The antiseptics analysed were hydrogen peroxide, povidone-iodine, cetylpyridinium chloride (CPC), essential oils, and chlorhexidine. ključnim riječima COVID i ispiranje usne šupljine ili vodica za ispiranje usne supljine, od kojih je jedna bila povezana s područjem oralne kirurgije.

\section{Rezultati}

S obzirom na to da se virus pojavio potkraj 2019. godine, mnogo je nepoznanica u terapiji pa ne iznenađuje činjenica da još uvijek ne postoje sigurni podatci koji pokazuju mogu li aktivni sastojci u vodici za ispiranje usta biti učinkoviti kada se koriste pri preoperativnom ispiranju ili kao dio oralne higijene pacijenta s bolešću COVID-19. Potkraj kolovoza 2020. godine bio je dostupan samo ograničeni broj radova povezanih $s$ virusom SARS-CoV-2 i dentalnom medicinom, a samo su u nekoliko njih predložene različite vrste aktivnih tvari za preoperativno ispiranje usta: 1-postotni vodikov peroksid, 1-postotni povidon-jodid (PVP-I), cetilpiridinijev klorid (CPC) 0,1-postotna eterična ulja i klorheksidin. Bitni zaključci citiranih članaka prikazani su u tablici 1 . Iz rezultata je očito da postoji visok stupanj heterogenosti između predloženih protokola i zato se predlaže analiza kritičkog pregleda koja će voditi kliničara pri odabiru.

Analizirani antiseptici bili su vodikov peroksid, povidonjodid, cetilpiridinijev klorid, eterična ulja i klorheksidin. 
Table 1 Published articles, reviews and guidelines reporting recommendations on preprocedural mouth rinses against infection of SARSCoV-2.

Tablica 1. Objavljeni članci, pregledi i smjernice u kojima se navode preporuke o pretproceduralnim ispiranjima usta u slučaju infekcije virusom SARS-CoV-2.

\begin{tabular}{|c|c|} 
Authors $\bullet$ Autor & $\begin{array}{c}\text { Publication } \\
\text { date } \\
\text { Datum } \\
\text { objavljivanja }\end{array}$ \\
\hline
\end{tabular}

Considerations on preprocedural mouth rinse $\bullet$ Razmatranja o preoperativnom ispiranju usne šupljine
Considered active principles $\bullet$

Proučavane tvari

"Agents such as $1 \%$ hydrogen peroxide or $0.2 \%$ povidone are recommended, for the purpose of reducing the salivary load of oral microbes, including potential 2019nCoV carriage.

Peng X et al. ${ }^{20}$

March 2020

Chlorhexidine, which is commonly used as mouth rinse in dental practice, may not be effective to kill 2019-nCoV. Since 2019-nCoV is vulnerable to oxidation, a preprocedural mouth rinse containing oxidative."

"Previous studies have shown that SARS and MERS were highly susceptible to povidone-iodine mouthwashes. Therefore, pre-procedural mouth rinse with $0,2 \%$ povidone-iodine might reduce the load of coronaviruses in saliva."

\begin{tabular}{|c|c|c|c|}
\hline $\begin{array}{l}\text { Ather A et al. }{ }^{25} \\
\text { (Article) }\end{array}$ & March 2020 & $\begin{array}{l}\text { "Previous studies have shown that SARS and MERS were highly susceptible to } \\
\text { povidone-iodine mouthwashes. Therefore, pre-procedural mouth rinse with } 0,2 \% \\
\text { povidone-iodine might reduce the load of coronaviruses in saliva." }\end{array}$ & Povidone-iodine \\
\hline $\begin{array}{l}\text { Li ZY, Meng LY. }{ }^{26} \\
\text { (Article) }\end{array}$ & February 2020 & $\begin{array}{l}\text { "Before oral examination, patients can rinse with } 1 \% \text { povidone-iodine, CPC }(0, \\
05 \%-0,10 \%) \text { or a mouthwash containing essential oils. In vitro papers show } \\
\text { gargling with povidone-iodine can inactivate SARS-CoV (responsible of } 2020 \\
\text { epidemic) and CPC could inactivate MERS-Cov." }\end{array}$ & $\begin{array}{l}\text { Povidone-iodine } \\
\text { Cetylpyridinium } \\
\text { chloride } \\
\text { Essential oils }\end{array}$ \\
\hline $\begin{array}{l}\text { Italian society of } \\
\text { Periodontology and } \\
\text { Implantology } \\
32 \\
\text { (Guidelines) }\end{array}$ & March 2020 & $\begin{array}{l}\text { "A rinse with a } 1 \% \text { solution of hydrogen peroxide (one part of hydrogen peroxide at } \\
10 \text { volumes / } 3 \% \text { and two parts of water) or with Povidone-iodine } 1 \% \text { could have an } \\
\text { effect on the viruses present in the patient's oral cavity, with final gargling for } 30 \text { sec. } \\
\text { Subsequently prescribe a further rinse with Chlorhexidine } 0.2-0.3 \% \text { mouthwash for } \\
1 \text { minute: Chlorhexidine does not appear effective in deactivating the virus, but is } \\
\text { able to reduce the bacterial load in the aerosol." }\end{array}$ & $\begin{array}{l}\text { Hydrogen peroxide } \\
\text { Povidone-iodine } \\
\text { Chlorhexidine }\end{array}$ \\
\hline $\begin{array}{l}\text { Ge ZY et al. }{ }^{33} \\
\text { (Article) }\end{array}$ & March 2020 & $\begin{array}{l}\text { "CHX is effective against several infectious viruses, including herpes simplex virus } \\
\text { (HSV), human immunodeficiency virus (HIV), and hepatitis B virus (HBV). About } \\
0.12 \% \text { CHX was used as a pre-procedural mouth rinse. For patients who develop } \\
\text { mucosal irritation or other side effects such as tongue stain, } 0.05 \% \text { CPC could be a } \\
\text { good alternative." }\end{array}$ & $\begin{array}{l}\text { Chlorhexidine } \\
\text { Cetylpyridinium } \\
\text { chloride }\end{array}$ \\
\hline $\begin{array}{l}\text { Australian Dental } \\
\text { Association }{ }^{34} \\
\text { (Guidelines) }\end{array}$ & March 2020 & $\begin{array}{l}\text { "While the efficacy of this approach cannot be guaranteed to have a significant } \\
\text { effect on viral load in a patient with COVID- } 19 \text {, we recommend that prior to } \\
\text { commencing treatment all patients should be asked to undertake a } 20-30 \text { second pre- } \\
\text { procedural mouth rinse with either: } \bullet 1 \% \text { hydrogen peroxide } \bullet 0.2 \% \text { povidone iodine } \\
\bullet 0.2 \% \text { chlorhexidine rinse (alcohol free) } \\
\text { - an essential oil mouth rinse (alcohol free)." }\end{array}$ & $\begin{array}{l}\text { Hydrogen peroxide } \\
\text { Povidone-iodine } \\
\text { Chlorhexidine (alcohol- } \\
\text { free) } \\
\text { Essential oils (alcohol- } \\
\text { free) }\end{array}$ \\
\hline $\begin{array}{l}\text { American Dental } \\
\text { Association }{ }^{36} \\
\text { (Guidelines) }\end{array}$ & March 2020 & $\begin{array}{l}\text { "Since SARS-CoV- } 2 \text { may be vulnerable to oxidation, use } 1.5 \% \text { hydrogen } \\
\text { peroxide (commercially available in the US) or } 0.2 \% \text { povidone as a preprocedural } \\
\text { mouth rinse. There are no clinical studies supporting the virucidal effects of any } \\
\text { preprocedural mouth rinse against SARS-CoV-2." }\end{array}$ & $\begin{array}{l}\text { Hydrogen peroxide } \\
\text { Povidone-iodine }\end{array}$ \\
\hline $\begin{array}{l}\text { Meng L, Hua F, } \\
\text { Bian Z. } 40 \\
\text { (Article) }\end{array}$ & March 2020 & $\begin{array}{l}\text { "Preoperative antimicrobial mouth rinse could reduce the number of microbes in the } \\
\text { oral cavity." }\end{array}$ & None \\
\hline $\begin{array}{l}\text { Basso } M \text { et al. }{ }^{42} \\
\text { (Review) }\end{array}$ & March 2020 & $\begin{array}{l}\text { "Considering the general costs for the patient and professional, availability on the } \\
\text { market, ease of use, interactions and side effects of the two principles that can be } \\
\text { used, the following treatment is suggested: } \\
\text { 1. Gargle with } 1 \% \text { hydrogen peroxide mouthwash for at least } 15 \\
\text { seconds with a final rinse of } 30 \text { seconds. When done, do not rinse with water but } \\
\text { immediately proceed to: } \\
\begin{array}{l}\text { 2. Rinse with } 0.20 \% \text { chlorhexidine mouth rinse for at least } 60 \text { seconds and } \\
\text { then gargle for at least } 15 \text { seconds. Do not rinse with water." }\end{array}\end{array}$ & $\begin{array}{l}\text { Hydrogen peroxide } \\
\text { Povidone-iodine } \\
\text { Chlorhexidine } \\
\text { Cetylpyridinium } \\
\text { chloride } \\
\text { Essential oils }\end{array}$ \\
\hline $\begin{array}{l}\text { Ahmed MS } 43 \\
\text { (Review) }\end{array}$ & February 2020 & $\begin{array}{l}\text { "A preoperational antimicrobial mouth rinse is generally used by many practitioners } \\
\text { to reduce the number of oral microbes. However, the National Health Commission } \\
\text { of the People's Republic of China advocated that chlorhexidine, which is commonly } \\
\text { used as mouth rinse in dental practice, may not be effective to kill corona virus. } \\
\text { Since corona virus is vulnerable to oxidation, preprocedural mouth rinse containing } \\
\text { oxidative agents such as } 1 \% \text { hydrogen peroxide or } 0.2 \% \text { povidone is recommended, } \\
\text { for the purpose of reducing the salivary load of oral microbes." }\end{array}$ & $\begin{array}{l}\text { Hydrogen peroxide } \\
\text { Povidone-iodine }\end{array}$ \\
\hline $\begin{array}{l}\text { Czech Dental } \\
\text { Association }^{44} \\
\text { (Guidelines) }\end{array}$ & March 2020 & $\begin{array}{l}\text { "Different solutions can be used as a pre-procedural mouth rinse, for example } 1 \% \\
\text { hydrogen peroxide, a combination of alcohol and } 0,2 \% \text { chlorhexidine (can be used } \\
\text { alone or in combination) or } 0,2 \% \text { povidone (restrictions for possible allergies)." }\end{array}$ & $\begin{array}{l}\text { Hydrogen peroxide } \\
\text { Chlorhexidine (with } \\
\text { alcohol) } \\
\text { Povidone-iodine }\end{array}$ \\
\hline
\end{tabular}

Hydrogen peroxide Povidone-iodine Chlorhexidine
(Article)
"Before oral examination, patients can rinse with $1 \%$ povidone-iodine, CPC $(0$ gargling with povidone-iodine can inactivate SARS-CoV (responsible of 2020

Periodontology and 


\begin{tabular}{|c|c|c|c|}
\hline Alharbi et al. ${ }^{45}$ & April 2020 & $\begin{array}{l}\text { "Using } 0.23 \% \text { povidone-iodine mouthwash for at least } 15 \mathrm{~s} \text { before the procedure can } \\
\text { reduce the viral load in the patient's saliva" }\end{array}$ & Povidone-iodine \\
\hline Fallahi et al. ${ }^{46}$ & April 2020 & $\begin{array}{l}\text { "The effect of chlorhexidine, which is commonly used for } \\
\text { pre-procedural mouth washing in dental practice, has not } \\
\text { yet been demonstrated to be capable of eliminating } 2019 \text { - } \\
\text { nCoV. However, oxidative agents containing mouth rinses } \\
\text { with } 1 \% \text { hydrogen peroxide or } 0.2 \% \text { povidone-iodine are } \\
\text { recommended" }\end{array}$ & $\begin{array}{l}\text { Hydrogen peroxide } \\
\text { Povidone-iodine }\end{array}$ \\
\hline Izzetti at al. ${ }^{47}$ & April 2020 & $\begin{array}{l}\text { "Mouth rinses containing } 1 \% \text { hydrogen peroxide or } 0.2 \% \text { povidone can be employed } \\
\text { to reduce microbial load in saliva, with a potential effect on SARS-CoV-2." } \\
\text { "The Italian recommendation documents are suggesting a preoperative } 1 \text {-min mouth } \\
\text { rinse with } 0.2 \% \text { to } 1 \% \text { povidone, } 0.05 \% \text { to } 0.1 \% \text { cetylpyridinium chloride, or } 1 \% \\
\text { hydrogen peroxide." }\end{array}$ & $\begin{array}{l}\text { Hydrogen peroxide } \\
\text { Povidone-iodine } \\
\text { Cetylpyridinium } \\
\text { chloride }\end{array}$ \\
\hline Ren et al. ${ }^{48}$ & April 2020 & $\begin{array}{l}\text { "Povidone-iodine mouthwash has been shown to have strong viricidal activities } \\
\text { against SARS-CoV and MERS-CoV after } 15 \mathrm{~s} \text { of exposure. (...) For aerosol- } \\
\text { generating procedures, patients should be instructed to use } 1 \% \text { povidone-iodine or } \\
1.5 \% \text { hydrogen peroxide mouth rinses for } 1 \text { min before the procedure." }\end{array}$ & $\begin{array}{l}\text { Hydrogen peroxide } \\
\text { Povidone-iodine }\end{array}$ \\
\hline O'Donnell et al. ${ }^{49}$ & May 2020 & $\begin{array}{l}\text { "Dental practitioners are at elevated risk of exposure to SARSCoV-2, and there are } \\
\text { guidelines that advocate the use of mouthwash clinically. } \\
\text { Preprocedural mouthwash to reduce the oral microbial load in patients undergoing } \\
\text { dental treatment in patients with SARS-CoV-2 is recommended by literature." }\end{array}$ & $\begin{array}{l}\text { Chlorhexidine } \\
\text { Povidone-iodine } \\
\text { Chlorinated Water } \\
\text { or Hypertonic Saline } \\
\text { Rinsing } \\
\text { Hydrogen peroxide } \\
\text { Quaternary ammonium } \\
\text { compounds }\end{array}$ \\
\hline $\begin{array}{l}\text { Kerawala et al. } .^{50} \\
\text { SPECIFIC TOPIC: SURGERY }\end{array}$ & May 2020 & $\begin{array}{l}\text { "The virucidal activity of PVP against SARS-CoV-2 has not been documented. } \\
\text { The suggestion that tempering Chlorhexidine rinses }\left(47^{\circ} \mathrm{C} \text { vs } 18^{\circ} \mathrm{C}\right) \text { may reduce } \\
\text { bacterial aerosol contamination further is untried with viral load." }\end{array}$ & $\begin{array}{l}\text { Povidone-Iodine } \\
\text { Chlorhexidine (tempered } \\
\left.47^{\circ}\right)\end{array}$ \\
\hline Kelly et al. ${ }^{51}$ & Jun 2020 & $\begin{array}{l}\text { "There is currently insufficient high-quality evidence to suggest that oral rinses are } \\
\text { effective against SARS-CoV-2. While a number of guidelines have suggested the use } \\
\text { of oral rinses as a prophylactic measure, this should not be as an alternative to high } \\
\text { quality personal protective equipment (PPE) and rigorous cross infection control" }\end{array}$ & $\begin{array}{l}\text { Chlorhexidine } \\
\text { Povidone-iodine } \\
\text { Hydrogen peroxide } \\
\text { Ethanol }\end{array}$ \\
\hline Dexter et al..$^{52}$ & Jul 2020 & $\begin{array}{l}\text { "Both agents (CHX and PVP-I) have broad activity against } \\
\text { bacteria and viruses that will serve to protect patients and providers from subsequent } \\
\text { transmission." }\end{array}$ & $\begin{array}{l}\text { Chlorhexidine } \\
\text { Povidone-iodine }\end{array}$ \\
\hline $\begin{array}{l}\text { Martinez-Lamas et } \\
\text { al. }{ }^{33} \\
\text { IN VIVO }\end{array}$ & Jul 2020 & $\begin{array}{l}\text { "These preliminary in vivo results suggest that a PVP-I rinse could reduce the saliva } \\
\text { viral load of SARS-CoV-2 in patients with higher viral loads. Therefore, routine } \\
\text { administration of PVP-I } \\
\text { could be primarily indicated for symptomatic patients infected with SARS-CoV-2." }\end{array}$ & Povidone-iodine \\
\hline Meister et al. ${ }^{54}$ & Jul 2020 & $\begin{array}{l}\text { "Experimental and clinical } \\
\text { research studies on SARS-CoV-2-related viruses showed that antiseptic solutions } \\
\text { containing chlorhexidine gluconate, PVP-I, chlorine dioxide, cetylpyridinium } \\
\text { chloride and hydrogen peroxide can indeed reduce viral loads." }\end{array}$ & $\begin{array}{l}\text { Chlorhexidine } 0,2 \% \\
\text { Povidone-iodine } \\
\text { Et. Essential Oils } \\
\text { Benzalconium Chloride } \\
\text { Hydrogen peroxide } \\
\text { Octenidine } \\
\text { Polyhexanide }\end{array}$ \\
\hline Moosavi et al. ${ }^{55}$ & Jul 2020 & $\begin{array}{l}\text { "The use of mouthwash before dental procedures to reduce the risk of transmission } \\
\text { of the virus to the dental team and the use of this mouthwash in COVID-19 patients } \\
\text { to help improve systemic problems associated with oral microbial flora." }\end{array}$ & $\begin{array}{l}\text { Chlorhexidine } \\
\text { Povidone-iodine } \\
\text { C31 G }\end{array}$ \\
\hline $\begin{array}{l}\text { Vergara- } \\
\text { Buenaventura et } \\
\text { Castro Ruiz. }\end{array}$ & Aug 2020 & $\begin{array}{l}\text { "Suggested recommendations: Gently gargle for } 30 \text { seconds in the oral cavity and } \\
30 \text { seconds in the back of the throat with: } 1.5 \% \text { or } 3 \% \mathrm{H} 2 \mathrm{O} 215 \mathrm{ml} \text {; PVP-I, } 0.2 \% \text {, } \\
0.4 \% \text {, or } 0.5 \% 9 \mathrm{ml} \text {; } 0.12 \% \text { CHX } 15 \mathrm{ml} \text {; or } 0.05 \% \text { CPC } 15 \mathrm{ml} . "\end{array}$ & $\begin{array}{l}\text { Chlorhexidine } \\
\text { Povidone-iodine } \\
\text { Hydrogen peroxide } \\
\text { Cetylpyridinium } \\
\text { Chloride }\end{array}$ \\
\hline $\begin{array}{l}\text { Eliades et al. } .^{57} \\
\text { ORTHODONTICS }\end{array}$ & Sep 2020 & $\begin{array}{l}\text { Preprocedural antiseptic protocol in orthodontics: } \\
\text { Mouthrinse with }\left(47^{\circ} \mathrm{C}\right) \mathrm{CHX} 0.12 \%-0.2 \% \text { for bacterial pathogens }(0.5-1 \mathrm{~min}) \text {. } \\
\text { Mouthrinse with } 0.2 \%-1 \% \text { PI or } 1 \% \mathrm{H} 2 \mathrm{O} 2 \text { for oxidation vulnerable viruses }(0.5-1 \\
\text { min) }\end{array}$ & $\begin{array}{l}\text { Chlorhexidine } \\
\text { Povidone-iodine } \\
\text { Hydrogen peroxide } \\
\text { Chloride dioxide } \\
\text { Herbal compounds } \\
\text { Cetylpiridinium chloride } \\
\text { Cyclodextrine \& } \\
\text { flavonoids }\end{array}$ \\
\hline
\end{tabular}




\section{Hydrogen peroxide (19)}

No specific literature addresses its virucidal activity against SARS-CoV-2. Peng et al. (20) reported that since the COVID-19 virus has been shown to be vulnerable to oxidation, as reported in the Guidelines for the Diagnosis and Treatment of Novel Coronavirus Pneumonia (5th edition), it is recommended to use a pre-procedural mouth rinse with hydrogen peroxide $1 \%$ to reduce the viral load. This recommendation is based on the behavior of other coronaviruses (21) exposed to hydrogen peroxide on different surfaces. Used in this way, a surface disinfectant with hydrogen peroxide $0.5 \%$ has proven effective in inactivating the virus in one minute (22).

\section{Povidone-iodine}

Povidone-iodine is an oxidising agent, which is also able to alter protein synthesis and lead to cell lysis. It is active against bacteria, viruses, fungi and spores. Povidone-iodine (PVP-I) is a compound obtained by combining the polyvinylpyrrolidone polymer (PVP) with iodine in the form of triiodide ions. Its possible role during SARS-CoV-2 pandemic has been reported by different publications (22-25).

\section{Cetylpyridinium chloride (CPC)}

Cetylpyridinium is active against bacteria, fungi and viruses. With regard to the SARS-CoV-2 coronavirus, the study by Li et al. (26) suggests that the right concentration of cetylpyridinium chloride should be between 0.05 and 0.10 if used as a preprocedural mouth rinse to reduce viral load of SARS-CoV-2.

\section{Essential oils}

Articles available for essential oils on SARS-CoV-2 are related to specific oils and concentrations (0.092\% eucalyptol, $0.064 \%$ thymol, $0.060 \%$ methyl salicylate and $0.042 \%$ menthol), (26). However, no clinical study has investigated an essential oil mouth rinse against SARS-CoV-2, either in vitro or in vivo.

\section{Chlorhexidine}

Chlorhexidine (27-30) is a biguanide considered the "gold standard" of chemical plaque control. The main side effects of chlorhexidine are linked to the formation of brownish-yellow pigmentation, although a recent review of the literature has demonstrated the efficacy of an anti-pigmenta-

\section{Vodikov peroksid (19)}

Nijedan se članak posebno ne bavi njegovom virucidnom aktivnošću protiv virusa SARS-CoV-2. Peng i suradnici (20) izvijestili su da se, zato što se pokazalo da je virus osjetljiv na oksidaciju, kako je navedeno u Smjernicama za dijagnostiku i liječenje nove koronavirusne upale pluća (5. izdanje), preporučuje uporaba 1-postotnog vodikova peroksida prije zahvata da bi se smanjilo virusno opterećenje. Ta se preporuka temelji na ponašanju ostalih koronavirusa izloženih vodikovu peroksidu na različitim površinama (21). Korištenje površinskog dezinficijensa s 0,5 -postotnim vodikovim peroksidom pokazalo se učinkovitim u inaktivaciji virusa unutar jedne minute (22).

\section{Povidon-jodid}

Povidon-jodid je oksidirajuće sredstvo koje može promijeniti sintezu proteina i potaknuti lizu stanica. Aktivno djeluje na bakterije, viruse, gljivice i spore. Povidon-jodid (PVP-I) je spoj dobiven kombiniranjem polivinilpirolidonskog polimera (PVP) s jodom u obliku trijodidnih iona. U radovima je objavljena moguća uporaba tijekom pandemije virusom SARS-CoV-2 (22 - 25).

\section{Cetilpiridinijev klorid (CPC)}

Cetilpiridinij aktivno djeluje na bakterije, gljivice i viruse. U slučaju koronavirusa SARS-CoV-2, Li i suradnici (26) u svojem istraživanju ističu da bi prava koncentracija cetilpiridinijeva klorida trebala biti između 0,05 i 0,10 ako se koristi za preoperativno ispiranje usta da bi se smanjilo opterećenje virusom SARS-CoV-2.

\section{Eterična ulja}

Članci o utjecaju eteričnih ulja na SARS-CoV-2 povezani su s određenim uljima i koncentracijama $(0,092 \%$ eukaliptola, 0,064 \% timola, 0,060 \% metil-salicilata i 0,042\% mentola) (26). No ni u jednoj kliničkoj studiji autori nisu istraživali sredstva za ispiranje usta s eteričnim uljima protiv virusa SARS CoV-2, bilo in vitro bilo in vivo.

\section{Klorheksidin}

Klorheksidin $(27$ - 30) je bigvanid koji se smatra zlatnim standardom kemijske kontrole plaka. Glavne nuspojave klorheksidina povezane su sa stvaranjem smećkasto-žute pigmentacije (29), iako je nedavni pregled literature pokazao djelotvornost anti-pigmentacijskog sustava u suzbijanju

\begin{tabular}{|c|c|c|c|}
\hline \multirow{3}{*}{ Disinfectant $\bullet$ Dezinficijens } & \multirow{2}{*}{\multicolumn{3}{|c|}{$\begin{array}{l}\text { Virus titer } \bullet \text { Titar virusa } \\
(\log \text { TCID } 50 / \mathrm{mL})\end{array}$}} \\
\hline & & & \\
\hline & $5 \mathrm{~min}$ & $15 \mathrm{~min}$ & $30 \mathrm{~min}$ \\
\hline Hand soap solution (1:49) • Sapun za ruke $(1: 49)$ & 3.6 & $\mathrm{U}$ & $\mathrm{U}$ \\
\hline Ethanol $70 \% \bullet$ Etanol $70 \%$ & $\mathrm{U}$ & $\mathrm{U}$ & $\mathrm{U}$ \\
\hline Povidone iodine $7.5 \% \bullet$ Povidon-jodid 7,5\% & $\mathrm{U}$ & $\mathrm{U}$ & $\mathrm{U}$ \\
\hline Chloroxylenol $0.05 \% \bullet$ Kloroksilenol $0,05 \%$ & $\mathrm{U}$ & $\mathrm{U}$ & $\mathrm{U}$ \\
\hline Chlorhexidine $0.05 \% \bullet$ Klorheksidin $0,05 \%$ & $\mathrm{U}$ & $\mathrm{U}$ & $\mathrm{U}$ \\
\hline Benzalkonium chloride $0.1 \% \bullet$ Benzalkonij-klorid $0,1 \%$ & $\mathrm{U}$ & $\mathrm{U}$ & $\mathrm{U}$ \\
\hline
\end{tabular}


tion system in counteracting the formation of chlorhexidine stains while maintaining the same efficacy $(29,30)$. As is the case with all other antiseptics, no available clinical study analyses the efficacy of chlorhexidine mouth rinse against SARSCoV-2 in dentistry in vivo. Lim and Kam (31) showed that chlorhexidine has an important virucidal action, even against coronavirus species. Moreover, Chin et al. (15) demonstrated the virucidal efficacy of chlorhexidine and other standard dental disinfectants.

\section{Discussion}

Many active substances commonly used in mouth rinses were demonstrated to be effective against SARS-CoV-2 in laboratory studies or if used as surface disinfectants (20-57). At the moment, there is still a gap in the knowledge pertaining to the practical usefulness of mouth rinses in a patient with SARS-CoV-2 before a surgical procedure. Therefore, at present, deductions can be based solely on the action mechanism, the data related to similar viruses from the past, results obtained in vitro or in other non-dental fields and actions on inanimate surfaces in the field of disinfection. Furthermore, a proposed practical procedure of use needs to be based on an analysis of how these active ingredients must be prepared and used and an evaluation of any side effects caused by use. Italian guidelines $(32,49)$ (Italy was the first European country to be heavily affected by COVID-19), together with other international recommendations, recommend the use of chlorhexidine, stating that it would be completely irrational to interrupt the commonly used pre-procedural mouth rinse with chlorhexidine and that, it should be maintained and used together with a second one, suggesting hydrogen peroxide $1 \%$ or povidone-iodine $1 \%$ (32-34).

Hydrogen peroxide is recommended for use as a mouth rinse at a concentration of $1 \%(20)$. Normally, the most frequently available formulation is $3 \%$, also described "for food use", and can be used as a disinfectant, mouth rinse, bleach for hair or nails and for animal care. A typical considerable production of gas bubbles could prevent its use for a sufficient time of at least 30 seconds. Hydrogen peroxide represents an extremely cost-effective product which can be found very easily on the market and has no important side effects other than slight local irritation or a burning sensation.

An increase in the use of povidone-iodine (PVP-I) 1\% mouth rinse at dental clinics has been verified since the beginning of February 2020, especially when the first recommendations of scientific societies appeared (20,26,32-38). However, some more technical information with respect to the same guidelines must be given to oral surgeons on possible allergies or issues related to the use of an iodine-based product. Attention must be paid not only to people with hyperthyroidism, but also to cases of latent or subclinical hyperthyroidism. The product is also known to interact with drugs, such as lithium-based antidepressants. Povidone-iodine should be avoided in patients with renal insufficiency.

From a pharmacological point of view, the official drug information sheet of the only povidone-iodine $1 \%$ mouthrinse (39) registered by the manufacturer under European klorheksidinskih mrlja, uz zadržavanje jednake učinkovitosti (30). Ni u jednoj dostupnoj kliničkoj studiji nije analizirana učinkovitost klorheksidinskog sredstva za ispiranje usta protiv virusa SARS-CoV-2 u dentalnoj medicini in vivo. Lim i Kam (31) pokazali su da klorheksidin ima važno virucidno djelovanje, čak i kad je riječ o nekim vrstama koronavirusa. Śtoviše, Chin i suradnici (15) dokazali su virucidnu djelotvornost klorheksidina i drugih standardnih oralnih dezinficijensa.

\section{Rasprava}

Mnoge aktivne tvari, koje se uobičajeno koriste za ispiranje usta, pokazale su se učinkovitima protiv virusa SARSCoV-2 u laboratorijskim ispitivanjima ili ako se koriste kao površinski dezinficijensi $(20-57)$. No još uvijek postoje neodgovorena pitanja koja se odnose na stvarnu učinkovitost ispiranja usta pacijenta s virusom SARS-CoV-2 prije kirurškoga postupka. Zato se zaključci mogu temeljiti isključivo na mehanizmu djelovanja određenog preparata, starijim podatcima o djelovanju na slične viruse, rezultatima dobivenim ispitivanjima in vitro ili ispitivanjima iz drugih područja kao, na primjer, iz područja dezinfekcije gdje se dobivaju podatci o djelovanju na neživim površinama. Nadalje, predloženi postupak uporabe mora se temeljiti na analizi kako se ti aktivni sastojci trebaju pripremiti i koristiti, te procjeni svih nuspojava prouzročenih njihovom uporabom. Talijanske smjernice $(32,49)$ (Italija je prva europska zemlja na koju je bolest izazvana virusom COVID-19 teško utjecala), zajedno $s$ drugim međunarodnim preporukama $(32-34)$, preporučuju primjenu klorheksidina navodeći da bi bilo potpuno iracionalno prekidati uobičajeno korištenje te tvari za ispiranje usta prije postupka te ga treba nastaviti upotrebljavati zajedno s drugim preparatima, poput 1-postotnog vodikova peroksida ili 1-postotnog povidon-jodida.

Vodikov peroksid preporučuje se za ispiranje usta u koncentraciji od $1 \%$ (20). Obično je najčešćc dostupna formulacija od $3 \%$ koja je također opisana za upotrebu u hrani, a može se koristiti kao dezinficijens, sredstvo za ispiranje usta, izbjeljivač za kosu ili nokte te za njegu životinja. Pri uporabi toga preparata stvaraju se mjehurići plina koji su neugodni za pacijenta te se zbog toga nesvjesno skraćuje njegova uporaba koja treba biti 30 sekundi. Vodikov peroksid iznimno je isplativ proizvod koji se vrlo lako može nabaviti na tržištu i nema značajnih nuspojava osim blage lokalne iritacije ili osjeta pečenja.

Povećano korištenje 1-postotnoga povidon-jodida (PVPI) za ispiranja usta u klinikama dentalne medicine potvrđeno je početkom veljače 2020., posebno kada su se pojavile prve preporuke znanstvenih društava $(20,26,32-38)$. No pri uporabi tih preparata za preoperativno ispiranje u oralnoj kirurgiji, treba voditi računa o mogućim alergijama ili problemima povezanima s uporabom proizvoda na bazi joda. Posebnu pažnju i oprez zahtijevaju osobe $s$ hipertireozom te $s$ latentnom ili supkliničkom hipertireozom. Također je poznato da su moguće i interakcije s lijekovima, poput one s antidepresivima na bazi litija. Povidon-jodid ne preporučuje se bolesnicima s bubrežnom insuficijencijom. 
regulations, specifically instructs users to "avoid the simultaneous use of other mouth, gums and throat disinfectants" and, more specifically, "not to use products containing hydrogen peroxide simultaneously on the part treated with this medication". This creates a possible conflict with some guidelines, which recommend the association between chlorhexidine and a choice between povidone-iodine or hydrogen peroxide to be used as a sequence of mouth rinses before operating sessions such as surgical procedures. Povidone-iodine mouthwash is still advised by many associations but only if it is not combined with any other substance, even if this means forfeiting the benefits of a second mouthwash with a different antimicrobial activity $(25,32,34,35)$.

Chlorhexidine is certainly the active ingredient most prescribed by dentists and best-known by patients. Chlorhexidine as an antiseptic has broad spectrum antimicrobial properties. The first publications on the new virus SARS-CoV-2 often questioned its efficacy, as no studies yet have demonstrated this action (20,26,32-40). However, some important in vitro studies have unequivocally shown the activity of chlorhexidine on many viral species, even at lower concentrations than those commonly used in mouth rinses $(31,54,58)$.

Coronaviruses are RNA viruses which are part of the order Nidovirales, suborder Cornidovirineae, family Coronaviridae, and subfamily Orthocoronavirinae. These viruses have their own viral envelopes with a positive-sense single-stranded genome and a helically symmetrical nucleocapsid. Therefore, if chlorhexidine is active against viruses with viral envelopes, it could be inferred that it might also be active against coronaviruses, including SARS-CoV-2.

Finally, chlorhexidine is considered to be the gold standard of oral antiseptics due to its substantivity, that is, the ability to bind to teeth and oral mucosa and be released for up to 12 hours (27). This property might also be important in combatting SARS-CoV-2, which continuously contaminates the oral cavity through saliva drops from salivary glands; however, the proper role of substantivity in reducing the spread of COVID-19 still has to be investigated.

Several publications related to SARS-CoV-2 specifically stress the importance of gargling $(20,26)$. Wölfel et al. (41) showed that pharyngeal virus shedding was very high during the first week of symptoms, and the RNA peak concentration was 1000 times higher compared to studies of SARS concentrations. SARS-CoV-2 was successfully isolated from throat swabs, which is another significant difference between COVID and SARS, as the latter rarely allowed successful live virus isolation from throat swabs. This reveals that the correct usage of virucidal oral products can be fundamental for preventing the spread of the virus via breathing, coughing and contact with the oral cavity

Therefore, before a surgical session, it is highly advisable that the patient not only rinses but also completes this procedure with a gargle in order to bring the rinse into the tonsillar area and into the proximity of the throat as much as possible.
S farmakološkog stajališta, službeni informativni list za 1\% povidon-jodid (39) koji je proizvođač registrirao prema europskim propisima, posebno upućuje korisnike da izbjegavaju istodobnu upotrebu drugih sredstava za dezinfekciju usta, desni i grla te osobito, da se istodobno ne koriste proizvodima koji sadržavaju vodikov peroksid na području koje se liječi ovim lijekom. To je u suprotnosti s određenim smjernicama (32) koje preporučuju korištenje klorheksidina te povidon-jodida ili vodikova peroksida za ispiranje usta prije operacijskih zahvata, poput kirurških. Mnoga udruženja $(25,32,34,35)$ i dalje preporučuju povidon-jodid za ispiranje usta, ali samo ako se ne kombinira s bilo kojom drugom tvari, iako to znači neiskoristivost drugog sredstva za ispiranje usta s različitim antimikrobnim djelovanjem.

Klorheksidin je aktivni sastojak koji doktori dentalne medicine sigurno najčešće propisuju, a pacijentima je najpoznatiji. Klorheksidin kao antiseptik ima antimikrobna svojstva širokoga spektra. U prvim tekstovima o novom virusu SARSCoV-2 $(20,26,32-40)$ često se dovodila u pitanje njegova učinkovitost jer nije bila potvrđena ni u jednoj kliničkoj studiji. No postoje ispitivanja in vitro koja su nedvosmisleno pokazala aktivnost klorheksidina na mnogim virusnim vrstama i pri nižim koncentracijama od onih koje se obično koriste za ispiranje usta $(31,54,58)$.

Koronavirusi su RNA virusi - dio reda Nidovirales, podreda Cornidovirineae, porodice Coronaviridae i potporodice Orthocoronavirinae. Spomenuti virusi imaju vlastite ovojnice $s$ pozitivnim osjetilnim jednolančanim genomom i spiralno simetričnom nukleokapsidom. Stoga, ako klorheksidin aktivno djeluje na viruse s virusnim ovojnicama, može se zaključiti da bi mogao biti aktivan i kad je riječ o koronavirusu, uključujući SARS-CoV-2.

Konačno, klorheksidin se smatra zlatnim standardom oralnih antiseptika (27) zbog svojih značajki - sposobnosti vezivanja za zube i oralnu sluznicu te oslobađanja aktivnih sastojaka do 12 sati. To bi svojstvo moglo biti važno i u borbi protiv virusa SARS-CoV-2 koji kontinuirano kontaminira usnu šupljinu kapljicama sline iz žlijezda slinovnica, no potrebna su daljnja istraživanja koja bi pokazala učinkovitost klorheksidina u smanjenju širenja virusa COVID-19.

$\mathrm{U}$ nekoliko radova povezanih $s$ virusom SARS-CoV-2 $(20,26)$ posebno se ističe važnost grgljanja. Wölfel i suradnici (41) pokazali su da je otpuštanje virusa iz područja farinksa bilo vrlo visoko tijekom prvog tjedna simptoma, a vršna koncentracija RNK bila je 1000 puta veća u usporedbi $s$ ispitivanjima koncentracija SARS-a. SARS-CoV-2 uspješno je izoliran iz brisova grla, što je još jedna značajna razlika između COVID-a i SARS-a, jer je ovaj drugi rijetko uspješno živ izoliran iz brisova grla. Ta činjenica upućuje na to da pravilna uporaba virucidnih oralnih proizvoda može biti iznimno važna u sprječavanju širenja virusa disanjem, kašljanjem i kontaktom $s$ usnom šuplijinom.

Zato se može zaključiti da je prije kirurškoga zahvata dobro da pacijent ne ispire samo usta, nego da dovrši taj postupak grgljanjem kako bi se tvar dovela što bliže području tonzila i u blizinu grla. 


\section{Conclusions}

As described and considered in this article, and on the basis of the available literature until late August 2020 and from the international guidelines for SARS-CoV-2, the area of 3 meters around the patient's mouth must be considered a high risk of contamination, and the use of effective mouth rinses can contribute in reducing the microbial load in aerosols. With regard to the mouth rinses, particularly before a surgical procedure, the following can be considered:

There is, yet, no mouth rinse which is scientifically proven to be effective against SARS-CoV-2 in the oral cavity. All guidelines or articles report activities against other types of viruses, and only a few contain data on the activity against SARS-CoV-2 in general, but not in the oral environment.

Oxidizing agents, such as hydrogen peroxide $1 \%$ and povidone-iodine (PVP-I) 1\%, are advised in many international guidelines and articles for possible use as a mouth rinse against SARS-CoV-2 (1,2,6-9).

Povidone-iodine $1 \%$ presupposes considerations on the patient's state of health. Side effects can be significant in the case of pregnancy, renal diseases, thyroid dysfunction or concomitant drug therapies. Simultaneous use of PVP-I and other disinfectants used as mouth rinses should be avoided.

Chlorhexidine was certainly proven to have antiviral activity against SARS-CoV-2 in laboratory studies (15). The substantivity of chlorhexidine to prolong antiseptic activity until 12 hours after a rinse can be an important tool against the virus. The advantages of this property in combating COVID-19 have been described by Yoon (58) but clinical confirmations are still missing.

It can be considered advantageous to use a sequence of 2 different types of active ingredients to exploit a dual mechanism of action, both oxidative and antiseptic. The most rational association could be a 30 " rinse with $\mathrm{H} 2 \mathrm{O} 2$ at a concentration of $1 \%$, followed by another 60 " rinse with Chlorhexidine at a concentration of $0.2-0.3 \%$. This sequence has been recently confirmed by the Italian scientific commission for national guidelines in dentistry against COVID-19 (59), and few other available studies (42,57). In case of allergies or intolerance to chlorhexidine, some authors $(26,32)$, suggested the use of cetylpyridinium chloride or essential oils as possible alternatives.

To follow the advice found in publications regarding SARS-CoV-2 and dentistry, preoperative rinsing should be completed with a gargle. There is no consensus in the literature on the ideal duration of a gargle, which can range from 10 to 30 seconds.

It can be concluded that the use of pre-procedural mouth rinses must be considered beneficial and important for the reduction of the load of SARS-CoV-2 virus in saliva and aerosols generated by dental procedures. However, mouth rinses represent only a part of the measures which oral surgeons must adopt in preventing the spread of COVID-19, since rinses alone do not solve the infection of SARS-CoV-2 and do not prevent the spread of contagious diseases.

\section{Zaključci}

$\mathrm{Na}$ temelju objavljenih podataka dostupnih iz literature i međunarodnih smjernica za SARS-CoV-2 do kraja kolovoza 2020. godine, područje od tri metra oko usta pacijenta mora se smatrati visokorizičnim, a korištenje učinkovitih sredstava za ispiranje usta može pridonijeti smanjenju mikrobiološkog opterećenja u aerosolima.

$\mathrm{O}$ učinkovitosti ispiranja usta prije kirurškoga postupka može se zaključiti sljedeće:

- Ne postoji metoda ispiranja usne šupljine za koju je znanstveno dokazano da je učinkovita protiv virusa SARS$\mathrm{CoV}-2$ u usnoj šupljini. Sve smjernice ili članci izvješćuju o aktivnostima protiv drugih vrsta virusa, a samo nekoliko sadržava podatke o aktivnosti protiv SARS-CoV-2 općenito, ali ne i u oralnom okružju.

- Oksidanti, kao što su $1 \%$ vodikov peroksid i $1 \%$ povidon-jodid preporučuju se u mnogim međunarodnim smjernicama i člancima $(1,2,6$ - 9) za upotrebu kao sredstvo za ispiranje usta u slučaju virusa SARS - $\mathrm{CoV}-2$.

- $1 \%$ povidon-jodid zahtijeva poznavanje zdravstvenog stanja pacijenta. Nuspojave mogu biti značajne u slučaju trudnoće, bubrežnih bolesti, poremećaja rada štitnjače ili u kombinaciji s drugim lijekovima. Preporuka je izbjegavati istodobnu uporabu povidon-jodida (PVP-I) i drugih dezinficijensa za ispiranje usta.

- Za klorheksidin je dokazano da antivirusno djeluje na SARS-CoV-2 u laboratorijskim ispitivanjima (15). Produljeno antiseptično djelovanje klorheksidina do 12 sati nakon ispiranja može biti učinkovito u suzbijanju virusa. Tu činjenicu istaknuo je u svojem radu Yoon (58) nakon praćenja pacijenata $s$ virusom COVID-19, ali još uvijek nedostaje klinička potvrda.

- Prednost je koristiti se dvama različitim preparatima za ispiranje usne šupljine jer se pritom iskorištavaju aktivni sastojci koji imaju dvostruki mehanizam djelovanja - oksidacijski i antiseptički. Optimalno bi moglo biti preoperativno ispiranje $s \mathrm{H}_{2} \mathrm{O}_{2}$ u koncentraciji od $1 \%$, nakon čega slijedi ispiranje klorheksidinom u koncentraciji od 0,2 do $0,3 \%$. Tu je sekvenciju nedavno potvrdilo talijansko Znanstveno povjerenstvo za nacionalne smjernice u stomatologiji za suzbijanje pandemije virusa COVID-19 (59) i nekoliko drugih dostupnih studija $(42,57)$. U slučaju alergija ili netolerancije na klorheksidin, neki autori $(26,32)$ predložili su upotrebu cetilpiridinijeva klorida ili esencijalnih ulja kao alternative.

- Preoperativno ispiranje trebalo bi se dovršiti grgljanjem. U literaturi nema jasnog stajališta o idealnom trajanju grgljanja - može biti u rasponu od 10 do 30 sekundi.

Može se zaključiti da je preoperativno ispiranje usta korisno i važno za smanjenje opterećenja virusom SARS-CoV-2 u slini i aerosolu koji nastaje. No ispiranje usta samo je dio mjera koje oralni kirurzi moraju poduzeti u sprječavanju širenja virusa COVID-19 jer samo ispiranje ne rješava problem infekcije tim virusom i ne prevenira zarazu. 


\section{Conflict of interest}

All authors declare no conflict of interest with a possible influence on conception, design, acquisition, analysis and drafting of the manuscript.

\section{Author contributions}

T.T., M.B. and G.B. - contributed to conception, design, data acquisition and analysis, drafted and critically revised the manuscript; H.L.W., A.D., C.V., I.M. - contributed to design and data acquisition, drafted and critically revised the manuscript; M.D.F. - contributed to conception, design, data acquisition, analysis, and interpretation, drafted and critically revised the manuscript. All authors have given final approval and they agree to be accountable for all aspects of the manuscript.

\section{Sukob interesa}

Svi autori izjavljuju da nisu bili u sukobu interesa s mogućim utjecajem na koncepciju, dizajn, prikupljanje podataka, analizu i izradu rukopisa.

\section{Doprinos autora}

T. T., M. B. i G. B. - pridonijeli su koncepciji, dizajnu, prikupljanju i analizi podataka te pisali tekst i i kritički revidirali rukopis; H. L. W., A. D., C. V., I. M. - pridonijeli su dizajnu i prikupljanju podataka, pisali su i kritički revidirali rukopis; M. D. F. - pridonio je koncepciji, dizajnu, prikupljanju podataka, analizi i interpretaciji, pisao je i kritički revidirao rukopis. Svi autori dali su konačno odobrenje i slažu se da će biti odgovorni za sve aspekte članka.
Sažetak

Cilj: Obaviti narativni pregled predloženih preoperativnih protokola za ispiranje usne šupljine prije oralno-kirurških zahvata da bi se u aerosolu suzbila pojavnosti virusa SARS-CoV-2. Izvori: Pretražene su znanstvene baze podataka PubMed, MedLine, CINAHN i Scopus kako bi se pronašli relevantni radovi objavljeni do trećeg tjedna travnja 2020. godine. Ovo istraživanje dopunjeno je pretraživanjem putem internetske tražilice te ručnim pretraživanjem međunarodnih i nacionalnih smjernica. Odabir istraživanja: Uključena su istraživanja i protokoli u kojima se predlaže preoperativno ispiranje usta kao mjera tijekom pandemije virusa COVID-19. S obzirom na to da je dostupan mali broj istraživanja, obavljen je pregled narativne literature. Ukupno se 15 referencija (11 članaka i 4 smjernice) smatralo mjerodavnima i kritički je analizirano. Zaključak: Rezultati pokazuju visoku heterogenost u predloženim protokolima. Potrebna su daljnja istraživanja da bi se bolje razumjele značajke i epidemiološka obilježja novog virusa te da bi se ispitala učinkovitost uobičajenih antiseptika protiv virusa SARSCoV-2 u budućim kliničkim ispitivanjima. No upotreba klorheksidina, vodikova peroksida, providonjodida i cetilpiridinijeva klorida, sa svrhom prevencije širenja bolesti uzrokovane virusom COVID-19, u različitim je časopisima opisana kao poželjna.
Zaprimljen: 22. lipnja 2020.

Prihvaćen: 24. rujna 2020.

Adresa za dopisivanje

dr. Matteo Basso

Via R. Galeazzi 4,

20161 Milano, Italija

matteo.basso@unimi.it

www.matteobasso.it

\section{Ključne riječi}

SARS virus; profesionalna izloženost; otopine za ispiranje usta; klinički protokoli; lokalna protuinfektivna sredstva

\section{References}

1. MeSH Browser [database on the Internet]. New York Times, Bureau of Labour Statistics, O*Net. 9 [cited 2020 Mar 24] Available from: https://www.nytimes.com/interactive/2020/03/15/business/economy/coronavirus-worker-risk.html.

2. Klyn SL, Cummings DE, Richardson BW, Davis RD, 2001. Reduc tion of bacteria-containing spray produced during ultrasonic scaling. Gen Dent. Nov-Dec 2001;49(6):648-52.

3. Wu Y-C, Chen C-S, Chan Y-J, 2020. The outbreak of COVID-19: an overview. J Chin Med Assoc. 2020 Mar;83(3):217-220.

4. Walls AC, Park YJ, Tortorici MA, Wall A, McGuire AT, Veesler D. Structure, function, and antigenicity of the SARS-CoV-2 spike glycoprotein. Cell. 2020 Apr 16;181(2):281-292.e6.

5. Fears AC, Klimstra WB, Duprex P, Hartman A, Weaver SC, Plante KS, e al. Comparative dynamic aerosol efficiencies of three emergent coronaviruses and the unusual persistence of SARS-CoV-2 in aerosol suspensions. medRxiv. $2020 \mathrm{Apr}$ 18;2020.04.13.20063784.

6. Marui VC, Souto MLS, Rovai ES, Romito GA, Chambrone L, Pannuti CM. Efficacy of preprocedural mouthrinses in the reduction of microorganisms in aerosol: A systematic review. J Am Dent Assoc. 2019 Dec;150(12):1015-1026.e1.

7. Gupta G, Mitra D, Ashok KP, Gupta A, Soni S, Ahmed S, Arya A. Efficacy of preprocedural mouth rinsing in reducing aerosol contamination produced by ultrasonic scaler: a pilot study. J Periodontol. $2014 \mathrm{Apr} ; 85(4): 562-8$.

8. Retamal-Valdes B, Soares GM, Stewart B. Effectiveness of a preprocedural mouthwash in reducing bacteria in dental aerosols: randomized clinical trial. Braz Oral Res. 2017;31:e21.

9. Gralton J, Tovey E, McLaws ML, Rawlinson WD. The role of particle size in aerosolised pathogen transmission: a review. J Infect. 2011 Jan;62(1):1-13.

10. Grenier D. Quantitative analysis of bacterial aerosols in two different dental clinic environments. Appl Environ Microbiol. 1995 Aug;61(8):3165-8.
11. Plotkowski MC, Bajolet-Laudinat O, Puchelle E. Cellular and molecular mechanisms of bacterial adhesion to respiratory mucosa. Eur Respir J. 1993 Jun;6(6):903-16.

12. Logothetis DD, Martinez-Welles JM. Reducing bacterial aerosol contamination with a chlorhexidine gluconate pre-rinse. JADA 1995;126(12):1634-1639.

13. Veena HR, Mahantesha S, Joseph PA, Patil SR, Patil SH. Dissemination of aerosol and splatter during ultrasonic scaling: a pilot study. J Infect Public Health. 2015; 8(3):260-265.

14. van Doremalen N, Bushmaker T, Morris D, Holbrook M, Gamble A, Williamson B, et al. Aerosol and surface stability of HCoV-19 (SARS-CoV-2) compared to SARS-CoV-1. medRxiv. 2020 Mar 13;2020.03.09.20033217.

15. Chin ACW, Chu JTS, Perera MRA, Hui KPY, Yen HL, Chan MCW, et al. Stability of SARS-CoV-2 in different environmental conditions. Lancet Microbe. 2020 May;1(1):e10.

16. Chen Y, Wang A, Yi B, Ding K, Wang H, Wang J, et al. The epidemiological characteristics of infection in close contacts of COVID-19 in Ningbo City. Zhonghua Liu Xing Bing Xue Za Zhi. 2020 May 10;41(5):667-671.

17. Lavezzo E. Suppression of COVID-19 outbreak in the municipality of Vo, Italy. Nature. 2020 Aug;584(7821):425-429.

18. He D, Zhao S, Lind Q, Zhuang Z, Cao P, Wang MH, Yang L. The relative transmissibility of asymptomatic COVID-19 infections among close contactsInt J Infect Dis. 2020 May;94:145-147.

19. Fernandez Mostajo M, van der Reijden WA, Buijs MJ, Beertsen W, Van der Weijden F, Crielaard W, et al. Effect of an oxygenating agent on oral bacteria in vitro and on dental plaque composition in healthy young adults. Front Cell Infect Microbiol. 2020 Aug 11;10:411.

20. Peng X, Xu X, Li Y, Cheng L, Zhou X, Ren B. Transmission routes of 2019-nCoV and controls in dental practice. Int J Oral Sci. 2020 Mar 3;12(1):9.

21. Goyal SM, Chander Y, Yezli S, Otter JA. Evaluating the Virucid- 
al Efficacy of Hydrogen Peroxide Vapour. J Hosp Infect. 2014 Apr;86(4):255-9.

22. Kampf G, Todt D, Pfaender S, Steinmann E. Persistence of Coronaviruses on Inanimate Surfaces and Their Inactivation With Biocidal Agents. Review. J Hosp Infect. 2020 Jun 17;S01956701(20)30285-1.

23. Eggers M, Eickmann M, Zorn J. Rapid and effective virucidal activity of povidone-iodine products against Middle East respiratory syndrome coronavirus (MERS-CoV) and modified vaccinia virus ankara (MVA). Infect Dis Ther. 2015; 4:491-501.

24. Geller C, Varbanov M and. Duval RE. Human Coronaviruses: Insights into Environmental Resistance and Its Influence on the Development of New Antiseptic Strategies. Review. Viruses. 2012 Nov 12;4(11):3044-68.

25. Ather A, Patel B, Ruparel NB, Diogenes A, Hargreaves KM. Coronavirus Disease 19 (COVID-19): Implications for Clinical Dental Care. J Endod. 2020 May;46(5):584-595.

26. Li ZY, Meng LY. The prevention and control of a new coronavirus infection in department of stomatology. Zhonghua Kou Qiang Yi Xue Za Zhi. 2020 Feb 14;55(0):E001.

27. Van der Weijden FA, Van der Sluijs E, Sebastian G Ciancio SG, Slot DE. Can Chemical Mouthwash Agents Achieve Plaque/Gingivitis Control? Dent Clin North Am. 2015 Oct;59(4):799-829.

28. Tartaglia GM, Kumar S, Fornari CD, Corti E, Connelly ST. Mouthwashes in the 21st Century: A Narrative Review About Active Molecules and Effectiveness on the Periodontal Outcomes. Expert Opin Drug Deliv. 2017 Aug;14(8):973-982.

29. Tartaglia G, Tadakamadla SK, Connelly ST, Sforza C, and Martín C. Adverse events associated with home use of mouthrinses: a systematic review. Ther Adv Drug Saf. 2019; 10: 2042098619854881.

30. Van Swaaij BWM, van der Weijden GAF, Bakker EWP, Graziani F, Slot DE. Does chlorhexidine mouthwash, with an anti-discoloration system, reduce tooth surface discoloration without losing its efficacy? A systematic review and meta-analysis. Int J Dent Hyg. 2020 Feb;18(1):27-43.

31. Lim KS, Kam PCA. Chlorhexidine - pharmacology and clinical applications. Anaesth Intensive Care. 2008 Jul;36(4):502-12.

32. MeSH Browser [database on the Internet]. Italian Society of Periodontology and Implantology \& Various Authors. COVID-2019: Standards for dental activity. [cited 12 March 2020]. Available from: www.sidp.it.

33. Ge ZY, Yang LM, Xia JJ, Fu XH, Zhang Y. Possible aerosol transmission of COVID-19 and special precautions in dentistry. J Zhejiang Univ Sci B. 2020 May;21(5):361-368.

34. MeSH Browser [database on the Internet]. Australian Dental Association, Managing COVID-19 Guidelines. [cited 12 March 2020]. Available from: www.ada.com.au.

35. MeSH Browser [database on the Internet]. Regional Federation of Associations of Doctors, Surgeons and Dentists of Lombardy. Coronavirus: indications for dentists in Lombardy. [cited 8 March 2020]. Available from: www.fnomceo.it.

36. MeSH Browser [database on the Internet]. American Dental Association. COVID-19 Resources for Dentists. Online information available at: www.ada.org. (Accessed 4 April 2020).

37. MeSH Browser [database on the Internet]. FDI World Dental Federation, COVID-19 guidelines from researchers based in Wuhan, China. [cited 2 April 2020]. Available from: www.fdiworlddental. org.

38. MeSH Browser [database on the Internet]. World Health Organization, Laboratory biosafety guidance related to coronavirus disease 2019 (COVID-19). Interim guidance. [cited 1 April 2020]. Available from: https://apps.who.int/iris/handle/10665/331138.

39. MeSH Browser [database on the Internet]. AIFA, Package informative sheet: information for the user: BETADINE 10\% mouthrinse. [cited 3 January 2020]. Available from: https://farmaci.agenziafarmaco.gov.it/aifa/servlet/PdfDownloadServlet?pdfFileName $=f$ ooter_000020_023907_Fl.pdf\&retry=0\&sys=m0b113.

40. Meng L, Hua F, Bian Z. Coronavirus Disease 2019 (COVID-19): Emerging and Future Challenges for Dental and Oral Medicine. J Dent Res ,2020 Mar 12
41. Wölfel R, Corman V, Guggemos W. Virological Assessment of Hospitalized Patients With COVID-2019. Nature 2020. https://doi. org/10.1038/s41586-020-2196-x

42. Basso M, Bordini G, Bianchi F, Prosper L, Testori T, Del Fabbro M. Efficacy of preprocedural mouthrinses to prevent SARS-CoV-2 (COVID-19) transmission: narrative literature review and clinical recommendations. Quintessenza Internazionale, 1/20 Marzo 2020. (Lang: ITA).

43. Ahmed MS, Barman D, Girish B, Devi RE, Kazi S, Bhure S, et al. Dental considerations in Corona Virus Infections: First review in literature. Journal of Advanced Medical and Dental Sciences Research. doi: 10.21276/jamdsr

44. MeSH Browser [database on the Internet]. Czech Dental Association, COVID-19 Guidelines. [cited 3 March 2020]. Available from: http://www.mzcr.cz/doKumenty/Kontakty-na-krajske-hygjenicke-stanice_18604_4122_1.html.

45. Alharbi A, Alharbi S, Alqaidi S. Guidelines for dental care provision during the COVID-19 pandemic. Saudi Dent J. 2020 May;32(4):181-186.

46. Fallahi HR, Keyhan SO, Zandian D, Kim SG, Cheshmi B. Being a front-line dentist during the Covid-19 pandemic: a literature review. Maxillofac Plast Reconstr Surg. 2020 Apr 24;42(1):12.

47. Izzetti R, Nisi M, Gabriele M, Graziani F. COVID-19 Transmission in Dental Practice: Brief Review of Preventive Measures in Italy. J Dent Res. 2020 Aug;99(9):1030-1038.

48. Ren YF, Rasubala L, Malmstrom H, Eliav E. Dental Care and Oral Health under the Clouds of COVID-19. JDR Clin Trans Res. 2020 Jul; 5(3):202-210.

49. O'Donnell VB, Thomas D, Stanton R, Maillard JY, Murphy RC, Jones SA, et al. Potential Role of Oral Rinses Targeting the Viral Lipid Envelope in SARS-CoV-2 Infection. Function (Oxf). 2020;1(1):zqaa002.

50. Kerawala C, Riva F. Aerosol-generating procedures in head and neck surgery - can we improve practice after COVID-19? Br J Oral Maxillofac Surg. 2020 Jul;58(6):704-707.

51. Kelly N, Nic Íomhair A, McKenna G. Can oral rinses play a role in preventing transmission of Covid 19 infection? Evid Based Dent. 2020 Jun;21(2):42-43.

52. Dexter F, Parra MC, Brown JR, Loftus RW. Perioperative COVID-19 Defense: An Evidence-Based Approach for Optimization of Infection Control and Operating Room Management. Review. Anesth Analg. 2020 Jul;131(1):37-42.

53. Martínez Lamas L, Diz Dios P, Pérez Rodríguez MT, Del Campo Pérez V, Cabrera Alvargonzalez JJ, López Domínguez AM, et al. Is povidone iodine mouthwash effective against SARS-CoV-2? First in vivo tests. Oral Dis. 2020 Jul 2:10.1111/odi.13526.

54. Meister TL, Brüggemann Y, Todt D, Conzelmann C, Müller JA, Groß Ret al. Virucidal efficacy of different oral rinses against SARSCoV-2. J Infect Dis. 2020 Jul 29:jiaa471.

55. Moosavi MS, Aminishakib P, Ansari M. Antiviral mouthwashes: possible benefit for COVID-19 with evidence-based approach. Journal of Oral Microbiology 2020, Jul Vol. 12, 1794363.

56. Vergara-Buenaventura A, Castro-Ruiz C. Use of mouthwashes against COVID-19 in dentistry. Br J Oral Maxillofac Surg. 2020 Aug 15:S0266-4356(20)30403-4.

57. Eliades T, Koletsi D. Minimizing the aerosol-generating procedures in orthodontics in the era of a pandemic: Current evidence on the reduction of hazardous effects for the treatment team and patients. Am J Orthod Dentofacial Orthop. 2020 Sep;158(3):330342.

58. Yoon JG, Yoon J, Song JY, Lim CS, Seong H, Noh JY, et al. Clinical Significance of a High SARS-CoV-2 Viral Load in the Saliva. J Korean Med Sci. 2020 May 25; 35(20): e195.

59. Gherlone E, Polimeni A, Fiorile F, Ghirlanda C, landolo R \& Technical-Scientifical commission of the Italian Ministry of Health. Operative Guidelines for the dental activity during phase 2 of the Covid-19 pandemic. [cited 15 May 2020]. Available from: https:// www.omceomi.it/docs/default-source/default-document-library/all-fase-2-testo-finale-indicazioni-operative-odontoiatri. pdf?sfvrsn $=0$ 